Document downloaded from:

http://hdl.handle.net/10251/167802

This paper must be cited as:

Mileto, C.; Vegas López-Manzanares, F.; García-Soriano, L.; Cristini, V.; Songel Gonzalez, JM.; Hernández Navarro, Y. (2017). "WITH YOUR HANDS" EDUCATIONAL INNOVATION PROJECT AT UPV (SPAIN): RESPONSE, ACCEPTANCE AND RESULTS. IATED. 77177723. http://hdl.handle.net/10251/167802

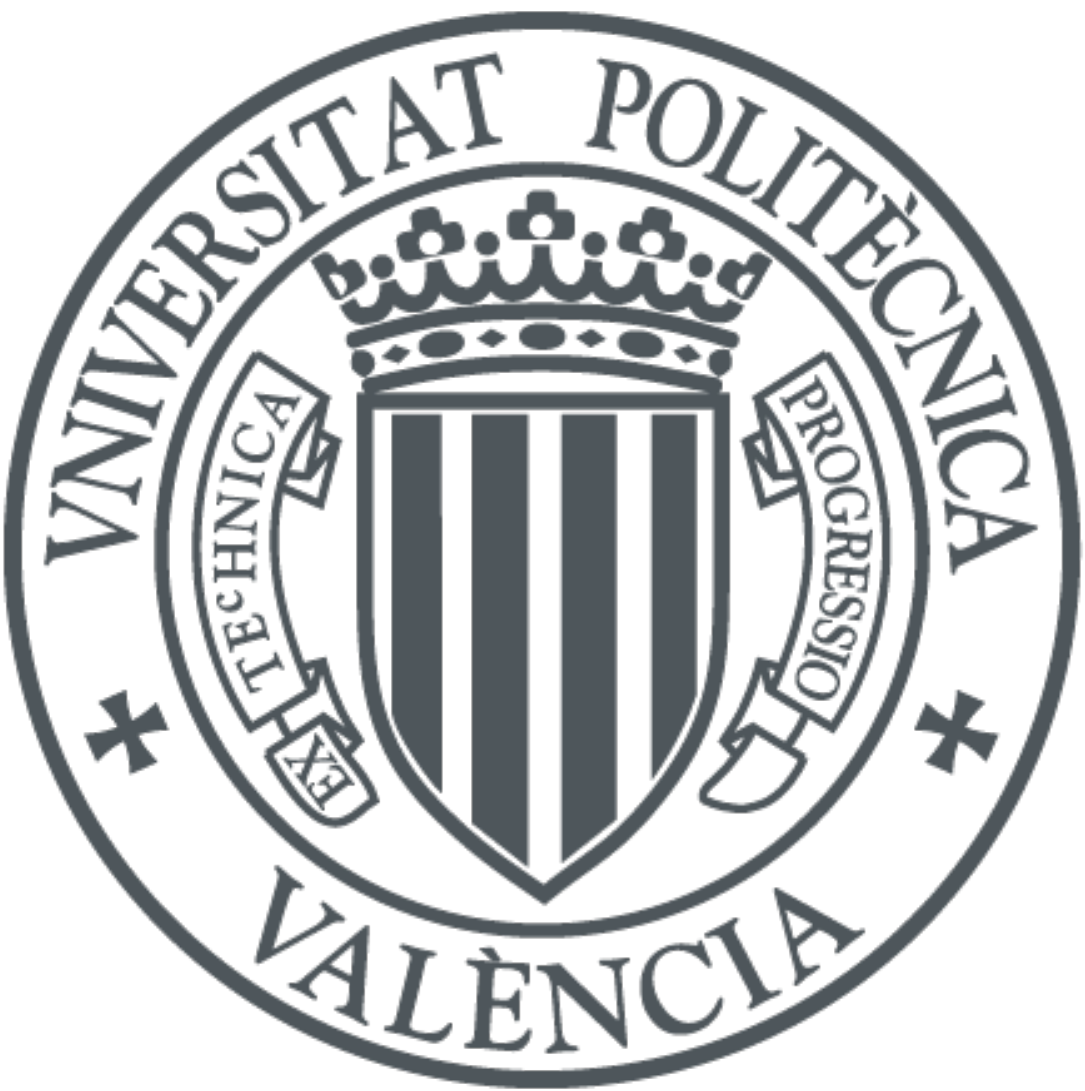

The final publication is available at

https://iated.org/archive/iceri2017

Copyright IATED

Additional Information 


\title{
"WITH YOUR HANDS" EDUCATIONAL INNOVATION PROJECT AT UPV (SPAIN): RESPONSE, ACCEPTANCE AND RESULTS
}

\author{
Camilla Mileto, Fernando Vegas López-Manzanares, Lidia García-Soriano, \\ Valentina Cristini, Juan María Songel, Yolanda Hernández Navarro \\ Universitat Politècnica de València, Spain
}

\begin{abstract}
This text presents the results obtained from an experimental educational innovation project implementing new learning methodologies in three subjects from the School of Architecture of the Universitat Politècnica de València (UPV). The main aim of this project is to bring earthen architecture closer to students in a more active and direct manner through practical construction experiences using earth.

These activities were carried out as part of experimental work sessions during which different practical workshops were held. The experiments and active methodologies proposed allow students to closely observe earth and different earthen constructive techniques, while learning about alternative techniques and promoting the valorisation of these constructive systems.

In order to obtain the desired objective feedback on the response, and the immediate and mediumterm development and impact of these activities among students, a survey was drawn up for students taking part (experimental group) as well as for students who were not (control group), and the data set obtained was analysed to establish whether this experience was positive for student learning. This direct feedback from students is crucial in the consolidation of the activity and to ascertain whether it answers the initial objectives set correctly or requires any adjustments, variations or changes.
\end{abstract}

Keywords: Innovation, feedback, active methodologies.

\section{INTRODUCTION}

\subsection{Context of the experience}

This text highlights the response, acceptance and results obtained from an innovative educational improvement, proposed and carried out at UPV in the 2016-2017 academic year as part of the "WITH YOUR HANDS. Earth as a material for the development of creative and constructive skills" Project for educational innovation and improvement (PIME).

This innovative project was carried out in three subjects in the department of Architectural Composition of the Higher Technical School of Architecture of UPV: Architectural Restoration (compulsory fifth-year subject), Composition (compulsory fourth-year subject) and Restoration of non monumental historical architecture (elective subject in the Master's course in Architecture). The main aim of this project was to bring earthen architecture closer to students in practical terms using active learning methodologies. Now that the project has been completed it is essential to evaluate it and ascertain as far as possible whether this innovation has improved teaching.

\subsection{Justification and motivation}

This project for educational innovation and improvement aims to experiment with the introduction into these three subjects of earth as a construction material. This has been implemented in all subjects through a series of activities for the students taking part, both joint and individual (specific activities for each subject). The activities proposed follow a "learning by doing" methodology (Rama et al. 1998) through which students learn about the material by working and experimenting with it directly. The project arose from the premise that earthen architecture is currently an appealing line of work in the construction of new contemporary architecture, as earth is a sustainable material which provides energy savings throughout the constructive process, thanks to its salubriousness and cultural 
relationship with the places we inhabit [1]. However, architecture schools rarely work with this material - often practically unknown to students - and in general the training of recently qualified architects displays major shortcomings in this field.

Thus, the aim of this innovation project is to ensure that the students involved gain a more in-depth knowledge of traditional earthen architecture, understanding its importance as local heritage, as well as the potential of earth in the design of a new more sustainable architecture. The main objective is therefore to learn about earth as a construction material and to apply its endless creative possibilities [2].

\section{METHODOLOGY}

A specific one-day activity common to all three subjects involved was carried out so that students could work jointly in order to meet the general objectives of the project.

Although not all students from the different subjects took part in this experimental activity, at the start of the year an experimental group of volunteers (approximately 90 students) agreed to participate. The one-day activity took place in the UPV campus, on the $8 \mathrm{H}$ site used by the research team for educational activities.

During this particular activity the students took part in four workshops on knowledge of earth as a material and different earthen constructive techniques (construction with rammed earth, adobe and earth renderings). For the purposes of organising the activity and ensuring the success of the workshops the students were divided into four groups which worked in rotation until all four proposed workshops had been completed.
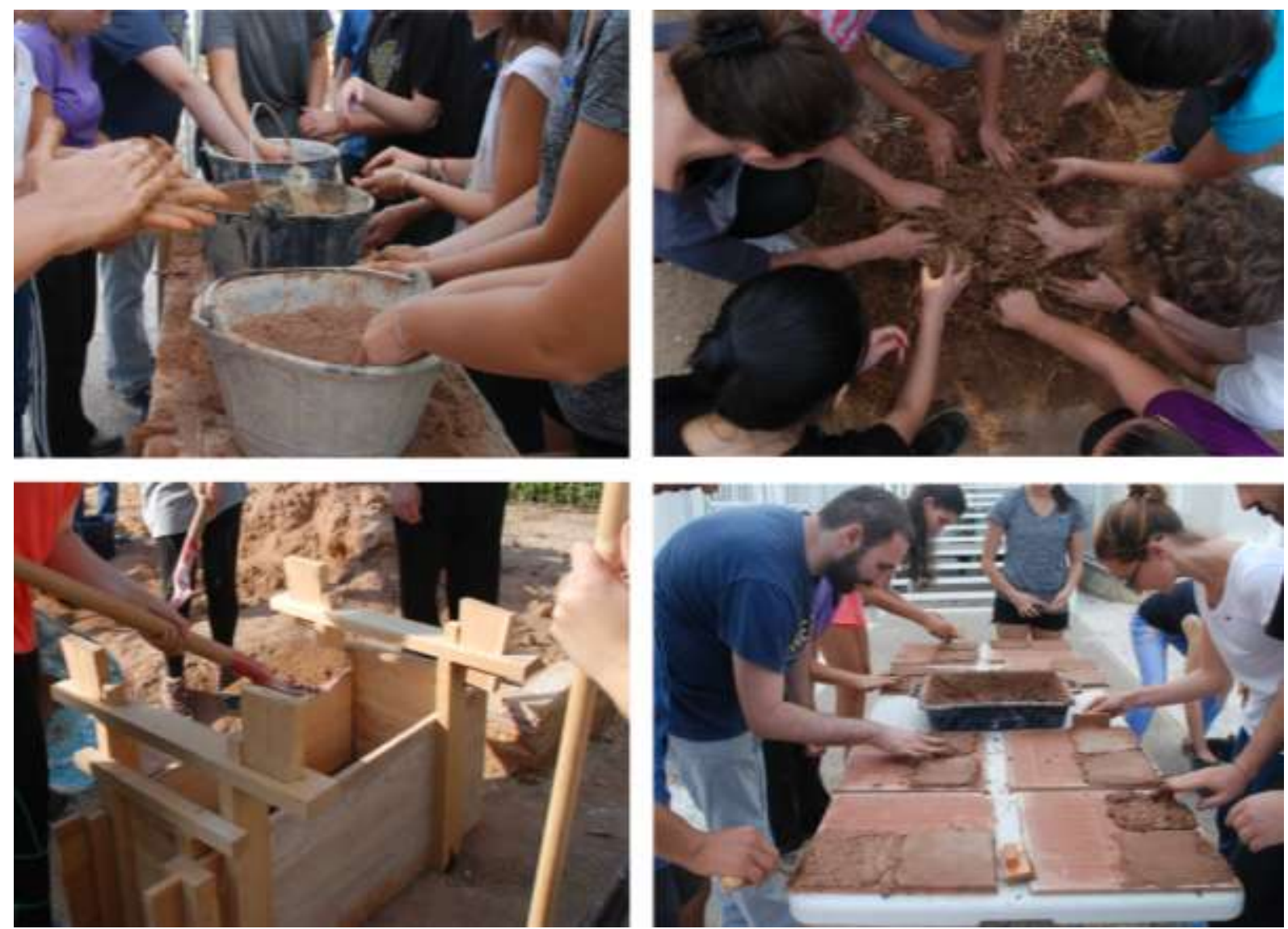

Figure 1. Images of the activities carried out during the one-day session. 
Subsequently, the specific learning acquired during this session was transferred to the subject curriculum and incorporated to the practical exercises carried out in individual activities. Students were invited to take part in this experimental activity and volunteers chose a case study for the practical work on earthen architecture.

\section{RESULTS}

Once prepared and completed, the phases of the teaching innovation activities of the project had to be assessed. The assessment of the project results (positive and/or improvable) was analysed through surveys of students, distributed among participating as well as non-participating volunteers.

Surveys were also carried out among teachers taking part in the project in order to ascertain the general level of satisfaction and motivation reached and to assess the project methodology with a view to possibly implementing or adapting it to all students of these subjects or others from the Higher Technical School of Architecture (e.g. Department of Architectural Constructions).

Several actions were used to promote the results of the project for educational innovation and improvement and students displayed the final work in an exhibition. As part of the project students from the experimental group prepared a presentation of the work for their classmates, explaining their experiences throughout.

\subsection{Development of the survey}

The surveys were drawn up and filled in using Google Forms given its ease of use and management of data obtained. In addition, the generation of virtual surveys greatly facilitated the collection of the necessary feedback from students, and in total 153 responses were obtained (72 responses from students taking part in the project and 81 from students who did not take part).

As this closed response survey focused on two main points it was divided into two blocks of questions. The first related to the individual personal experiences of students in the workshop (experience obtained if taking part or reasons for choosing not to take part), while the second focused on matters relating to earthen architecture in order to compare the results in this field and the actual improvement potentially brought about by this type of direct immersion in the study of earth as a material both for participants and non-participants in the workshops.

Therefore, the following questions were asked:

- Did you take part in the experimental earthen workshop?

Questions for participating students (experimental group):

- Do you believe the workshop improved your knowledge of earthen architecture?

- Do you believe your experience in the workshop has helped improve your practical work?

- In your opinion, to what extent has the workshop improved the relationships between members of the workgroup?

- Do you consider this activity to have been useful to the subject in general?

Questions for non-participating students (control group):

- Would you have liked to take part in the workshop?

- Why did you choose not to take part?

- Do you think these initiatives could be of use in the learning process?

Questions about earthen architecture for all students:

- In order to make adobe the earth has to be...

- In order to build a rammed-earth wall the earth has to be... 
- In order to execute earth rendering, what elements can be added to improve its resistance?

- What particles act to bond earth?

\subsection{Methodology and techniques used to treat and analyse data}

On completion of the experiment a survey was drawn up and filled in by 153 students from the experimental and control groups (82 from the experimental group and 71 from the control group).

Given that this type of sample is not probabilistic (as students participated voluntarily and were not selected at random), this sample is seen as a sample of convenience, and the sample error has been calculated considering the greatest variability possible $(p=0.5$ and $q=0.5)$. Considering the first type $\alpha=$ $5 \%$ and a level of trust of $95 \%$ the result obtained is $z=1.96$.

Therefore, with the sample error formula $=\sqrt{ }(p \cdot q \cdot z 2 / n \cdot N-n / N-1)$

where $N$ is the total number of students of the subject who have taken part in the experiment $=293$ and $\mathrm{n}$ the number of students who answered $=153$,

the sample error obtained was $5.48 \%$ which can be considered acceptable.

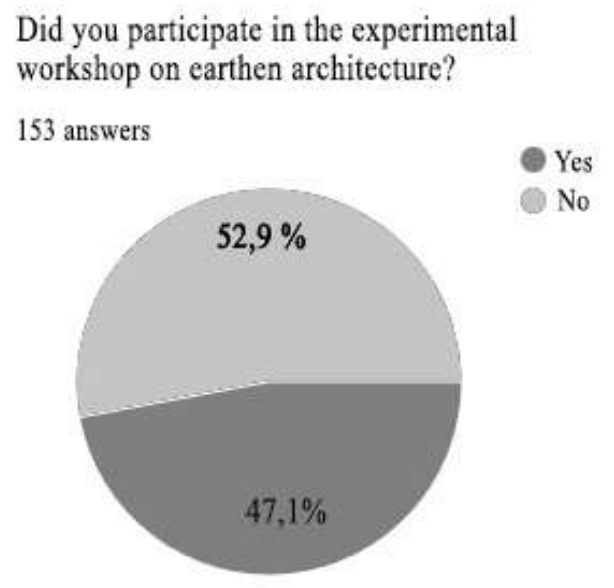

Figure 2. List of students who took part in the survey

In terms of responses, the sample error for the experimental group was $5.37 \%$, while that for the control group was $8.37 \%$ (as proportionally fewer students from this group completed the survey).

\subsection{Acceptance of the experience}

The first block of the survey focused on ascertaining the acceptance of the innovation among both the experimental group and the control group.

\subsubsection{Acceptance of the experience of participating students}

Most of the participants in the experimental workshops (65.3\%) believe that the experience improved their knowledge of earthen architecture, while $31.9 \%$ felt that their knowledge was greatly improved.

In addition $48.6 \%$ consider the workshop to have been extremely helpful for practical work and most of the students in the group (98.6\%) believe that this activity is useful for the subject.

Given the above it can be stated that the students taking part in the experiment were satisfied. 
Do you believe the workshop improved your knowledge of carthen architecture?

72 answers

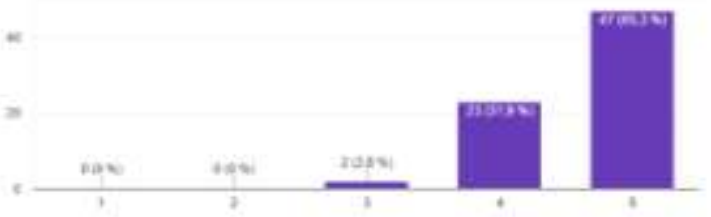

In your opinion, to what extent has the workshop improved the relationships between members of the workgroup?

72 answers

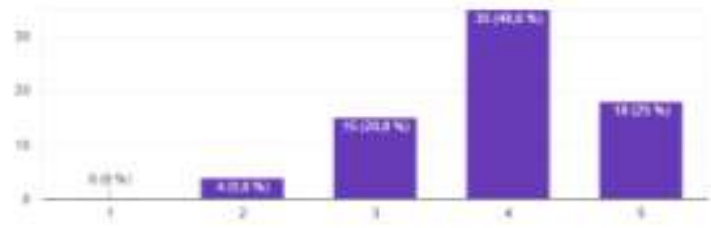

Do you believe your experience in the workshop has helped improve your practical work?

72 answers

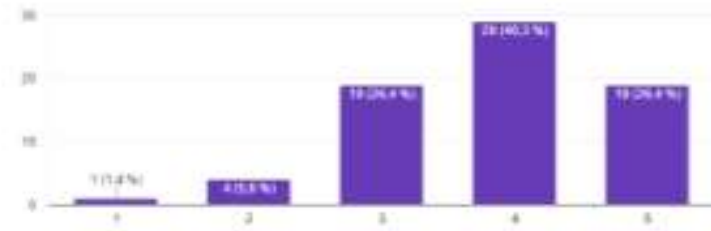

Do you consider this activity to have been useful to the subject in eeneral?

72 answers

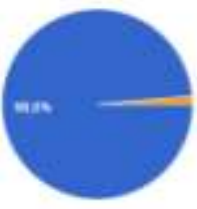

Figure 3. Responses from the experimental group

\subsubsection{Acceptance of the experience among non-participating students}

In contrast, it was vital to ascertain the opinion of students who did not take part in the innovation. Most of the students who did not take part in the workshop (92.6\%) answered that they would have liked to and that they consider this initiative to be interesting and useful for learning. However, there were two main reasons why they chose not to take part: lack of time $(45.7 \%)$ and the limited number of places available despite their interest (49.4\%).

Would you have liked to take part in the workshop?

81 answers

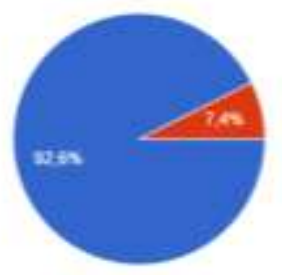

- Yas

Do you think these initiatives could be of use in the learning process? 81 answers

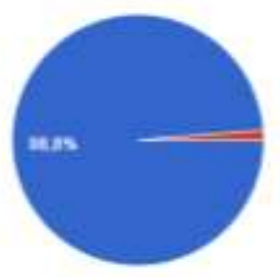

Why did you choose not to take part?

81 answers

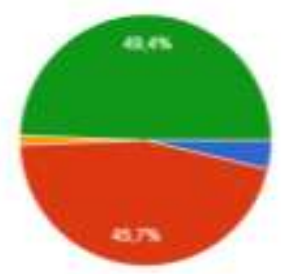

Trm not interented in the shied

Ihave so time

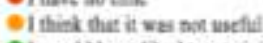

-1 would have liked tis purticipate bet there sere so place:

Figure 4. Responses of the control group 


\subsection{Results of the improvement in the teaching-learning process}

The second part of the survey focused on specific knowledge of earthen architecture, with four simple questions on the topic.

A series of specific conclusions was reached from the responses to these questions.

The four questions were answered correctly by approximately $65 \%$ of students. However, it is important to view these results in terms of participation or non-participation in the workshop.

In order to make adobe the earth has to be..

146 answets
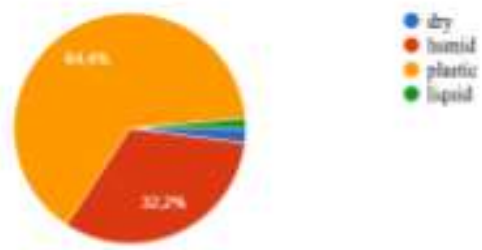

In order to build a rammed-earth wall the earth has to be. 144 answers
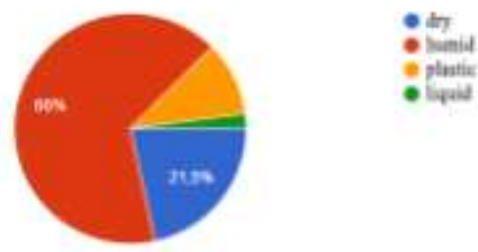

\begin{tabular}{|l|c|c|}
\hline $\begin{array}{l}\text { Questions } \\
\text { answered } \\
\text { correctly }\end{array}$ & $\begin{array}{c}\text { Control Group } \\
\text { (81 answers) }\end{array}$ & $\begin{array}{c}\text { Experimental Group } \\
\text { (72 answers) }\end{array}$ \\
$\begin{array}{l}\text { Question 1 } \\
\text { Question 2 }\end{array}$ & $35(42,68 \%)$ & $58(81,7 \%)$ \\
Question 3 & $43(45,12 \%)$ & $55(77,46 \%)$ \\
Question 4 & $46(56 \%)$ & $46(64,7 \%)$ \\
\hline
\end{tabular}

Figure 5. Comparison of responses of both groups in the second block of questions

Therefore, from the analysis of responses to these questions in each group it can be concluded that $40 \%-50 \%$ of the students who did not take part in the workshop answered correctly, but these percentages increase noticeably to $75-80 \%$ for correct responses from participating students. Hence a clear improvement is seen in the percentage of correct answers and in the knowledge of contents (the difference is less pronounced in question 3). 


\section{CONCLUSIONS}

Starting from the premise that earthen architecture is currently an attractive line for the construction of new architecture, this project for educational innovation and improvement has brought earthen architecture closer to architecture students in a direct and experimental manner. The interest in finding out about earthen architecture as part of the vernacular architectural heritage of our region lies in the fact that the protection, conservation and restoration of this heritage are based on its knowledge, respect and valorisation.

The importance of this type of learning initiative based on active methodologies (Moore et al. 2002) is increasingly apparent, as is the demand for such activities among university students who are generally used to learning in master classes where they are mere spectators. This means that they are extremely enthusiastic towards these new learning experiences in which they are in control of their own learning (Bautista Martínez 2012). In addition, experiencing the material directly has provided students with a more in-depth knowledge than would have been attained following a more traditional methodology in a classroom. It is therefore worth noting the importance of this type of innovative action with "learning by doing" methodologies based on direct experience and active participation, and increasingly popular in university teaching.

The results of the surveys were very satisfactory and provided important feedback that will allow some activities to be adjusted and adapted. Following the assessment of this innovation it can be stated that the experience was well received among students, encouraging and improving their knowledge of earthen architecture, and was therefore a better learning methodology than traditional master classes.

\section{ACKNOWLEDGEMENTS}

This text is part of the Project in educational innovation and improvement "WITH YOUR HANDS. Earth as a material for developing creative and constructive skills" ("CON LAS MANOS. La tierra como material para el desarrollo de las capacidades creativas y constructivas") (code A06, 2016-2017 academic year, main teacher: Camilla Mileto), funded by the Vice-Rectorate for Studies, Quality and Accreditation of Universitat Politècnica de València.

\section{REFERENCES}

[1] AA.VV. (2014). Versus: lessons from vernacular heritage to sustainable architecture = leçons du patrimoine vernaculaire pour une architecture durable. Grenoble, CRAterre-ENSAG; http://www.esg.pt/versus/images/pdf/versus_booklet.pdf.

[2] CRATERRE-ENSAG, ANGER, R. y FONTAINE, L. (2005). Grains de batisseurs, la matière en grains, de la géologie à l'architecture, CRAterre Edition. 2005.

[3] AAVV (1992). Arquitectura. Directrices para los Planes de Estudio. Antecedentes. Junta de Directores de las Escuelas Técnicas Superiores de Arquitectura, January 1992, Editorial PROUN Internacional P.F.C.

[4] ALONSO, C. GALLEGO, D. y HONEY, P. (1994). Los estilos de aprendizaje procedimiento de diagnóstico y mejora, Ediciones Mensajero, Bilbao, 1994.

[5] ARENDS, R. (2007). Aprender a enseñar. McGraw-Hill, Mexico.

[6] BAUTISTA MARTÍNEZ, J. (2012). Innovación en la universidad: prácticas, políticas y retóricas, Grao Ed., Barcelona, 2012.

[7] MOORE, S., WALSH, G. y RíSQUEZ, A. (2002). Estrategias Eficaces Para Enseñar En La Universidad. Guía Para Docentes Comprometidos. Narcea Ed., Madrid.

[8] RAMA, V. DASARATHA y ZLOTKOWSKI, E. A. (1998). Learning by Doing: Concepts and Models for Service-Learning in Accounting. Washington, D.C.: American Association for Higher Education. 